\title{
Evaluation of recombinant proteins of Neospora caninum as vaccine candidates (in a mouse model) ${ }^{*}$
}

\author{
John Ellis ${ }^{\mathrm{a}, *}$, Catherine Miller ${ }^{\mathrm{a}, 1}$, Helen Quinn ${ }^{\mathrm{a}, 2}$, Cheryl Ryce ${ }^{\mathrm{a}}$, Michael P. Reichel ${ }^{\mathrm{b}, 3}$ \\ ${ }^{a}$ Department of Cell and Molecular Biology, University of Technology, Sydney, P.O. Box 123, New South Wales 2007, Australia \\ b Novartis Animal Health Australasia Pty. Ltd., "Yarrandoo" R\&D Centre, 245 Western Road., Kemps Creek, New South Wales 2171 , Australia
}

Keywords: Neospora caninum Abortion Recombinant protein Mouse model Transplacental transmission

Live vaccine

\begin{abstract}
a b s t r a c t
Abortion, resulting from infections by the parasite Neospora caninum, is a major cause of economic loss to both the dairy and beef industries of cattle-producing countries of the world. Vaccination as a means of preventing abortion and/or infection represents a viable control strategy; indeed a commercial vaccine is available in some countries, albeit of unknown efficacy. The commercial vaccine is based on inactivated tachyzoites of N. caninum but other approaches based on lysates and recombinant antigens of N. caninum may also be feasible. In this study we have used an immunisation/challenge model of transplacental transmission, based on the Qs mouse with an Nc-Liverpool challenge, to investigate the vaccine potential of a number of formulations based on four recombinant proteins of N. caninum (GRA1, GRA2, MIC10, and p24B). All formulations studied were immunogenic in the mouse when assessed by ELISA using sonicated tachyzoite antigen as the target antigen. In one experiment, a mixture of MIC10 and p24B produced partial protection against transplacental transmission of $\mathrm{N}$. caninum in this mouse model; in contrast a live infection of tachyzoites of NC-Nowra given before pregnancy always induces very high levels of protective immunity. The field of vaccines against Neospora-associated abortion in cattle is discussed.
\end{abstract}

\section{Introduction}

Abortion, resulting from infections by the parasite Neospora caninum, is a major cause of economic loss to both the dairy and beef industries in Australia and other cattle producing countries of the world. Annual losses in calf and milk production were estimated to be $\$ 21$ million in Australia alone [1]. Infections in dogs (if caught early enough) may be treated with drugs however treatment options in food-producing animals are limited. Hence, efficacious vaccines for the control of neosporosis are urgently needed, as

\footnotetext{
* The nucleotide sequence data reported in this paper is available from the GenBank database under the accession number FJ211062.

* Corresponding author. Current address: Department of Medical and Molecular Biosciences and Institute for Biotechnology of Infectious Diseases, University of Technology, Sydney, P.O. Box 123, New South Wales 2007, Australia. Tel.: +6129514 4161; fax: +61295148206.

E-mail address: john.ellis@uts.edu.au (J. Ellis).

1 Current address: Institute for Biotechnology of Infectious Diseases, University of Technology, Sydney, P.O. Box 123, New South Wales 2007, Australia.

2 Current address: National Centre for Immunisation Research and Surveillance, The Children's Hospital at Westmead, Locked bag 4001, Westmead, New South Wales 2145, Australia.

3 Current address: Gribbles Veterinary Pathology, P.O. Box 536, Palmerston North, New Zealand.
}

infections are now recognised as exceedingly common in cattle [2].

Vaccines based on live parasites are available for a range of other diseases and used successfully and extensively around the world. For example, live vaccines are available for besnoitiosis in cattle [3], Toxoplasma-induced abortion in sheep [4] and coccidiosis in poultry [5]. It is significant that all these successful vaccines are against coccidia that are closely related to N. caninum. The success of the live vaccine against Toxoplasma gondii-induced abortion in sheep demonstrates that foetal loss is preventable, raising the prospect that a vaccine to prevent Neospora-associated abortion should be feasible. Transmission of the parasite from dam to offspring is the major route of infection for $\mathrm{N}$. caninum, and controlling that route of the life cycle of the parasite is potentially needed as a prerequisite for a vaccine that prevents abortions.

A vaccine for the prevention of neosporosis in cattle should, at a minimum, prevent abortion in cattle. A commercial vaccine against bovine neosporosis based on an inactivated $\mathrm{N}$. caninum tachyzoite preparation [Bovilis ${ }^{\circledR}$ Neoguard, Intervet] is available in some countries of the world. An evaluation of this vaccine in field studies [6-9] showed that vaccination with Bovilis ${ }^{\circledR}$ Neoguard did reduce the incidence of abortion. Heuer et al. [8] reported a $24.6 \%$ reduction in abortion when compared to controls for Bovilis ${ }^{\circledR}$ Neoguard. Barajas-Rojas et al. [6] describe abor- 
tion rates of $12 \%$ and $29 \%$ in vaccinated and placebo groups, respectively.

Recombinant vaccines preventing neosporosis in cattle will have the advantage of being cheaper to manufacture, and a focussed selection of the relevant antigens involved might also be able to selectively target immune responses that are important in the prevention of abortion as opposed to preventing infection. In recent years, studies on the molecular characterisation of $\mathrm{N}$. caninum have resulted in the molecular cloning of a variety of genes coding for antigens $[10,11]$. Many of these antigens represent potential new vaccine candidates. The approaches used for gene discovery to date have focussed on immunoscreening cDNA expression libraries [12] or the generation of expressed sequence tags (ESTs [13]). Such studies have resulted in the isolation of homologues of genes previously described in T. gondii, such as the SAG, GRA and MIC genes, all of which are intimately involved in the invasion process of the host cell and therefore important in determining the outcome of the parasite/host relationship.

Animal models, both mouse and cattle, exist to evaluate many of these candidates for their potential as vaccines against neosporosis $[14,15]$. In this study we have used an immunisation/challenge mouse model of transplacental transmission to investigate the vaccine potential of a number of formulations based on four recombinant proteins of N. caninum (GRA1, GRA2, MIC10, and p24B). The first three of these proteins were chosen since they are excreted/secreted by $\mathrm{N}$. caninum during the active invasion process of a host cell, and thus thought to represent key molecules involved in the initiation of infection. The protein $\mathrm{p} 24 \mathrm{~B}$ was included because no knowledge was available about this molecule from the literature on cyst-forming coccidia, and database searches implied it was potentially a novel protein.

\section{Materials and methods}

\subsection{Parasites}

N. caninum tachyzoites of NC-Nowra and NC-Liverpool were maintained by continuous cell passage in Vero cells (using RPMI and heat inactivated horse serum) at $37{ }^{\circ} \mathrm{C}$ in an atmosphere containing $5 \% \mathrm{CO}_{2}$. Parasites were harvested from culture and then passed through a $26 \mathrm{G}$ needle to lyse any remaining intact Vero cells. Tachyzoites were centrifuged at $500 \mathrm{~g}$ for $10 \mathrm{~min}$ and the pellet resuspended in sterile $0.9 \%$ saline. Parasites were counted using a Neubauer haemocytometer and diluted in sterile $0.9 \%$ saline to achieve the required dose for injection [14].

A lysate from NC-Nowra tachyzoites was prepared as follows. Pellets were resuspended in lysis buffer $(20 \mathrm{mM}$ Tris- $\mathrm{Cl} \mathrm{pH} 7.5$, $0.15 \mathrm{M} \mathrm{NaCl}, 1 \%$ Triton X-100, $1 \mathrm{mM}$ Ethylenediaminetetraacetic acid, $1 \mathrm{mM}$ Benzamidine, $1 \mathrm{mM}$ Phenymethylsulphonyl fluoride and $2 \mathrm{mM}$ Dithiothreitol) and incubated on ice for $1 \mathrm{~h}$. The suspension was then sonicated three times at $50 \mathrm{~W} / 20 \mathrm{KHz}$ for $15 \mathrm{~s}$ and spun at $3000 \mathrm{~g}$ for $10 \mathrm{~min}$ to remove insoluble debris. The lysate was dialysed overnight at $4{ }^{\circ} \mathrm{C}$ against $\mathrm{PBS}$ and the protein concentration was determined using a Lowry protein assay.

\subsection{B Characterisation}

\subsubsection{Identification and characterisation of $24 \mathrm{~B}$ cDNA}

A cDNA library from Nc-Liverpool was used in these studies [12]. A recombinant phage plaque from this library (called 24B), chosen randomly from the library, was picked into double distilled water and subject to PCR amplification using primers FpB $\left(5^{\mathrm{t}}\right.$ GTAAAACGACGGCCAGT $\left.3^{\mathrm{t}}\right)$ and RpB2 ( $5^{\mathrm{t}}$ GCCGCTCTAGAACTA3 $\left.{ }^{\mathrm{t}}\right)$ whose priming sites flank the cloning site. A $50 \curvearrowright 1$ PCR reaction was used with $2.5 \mathrm{mM} \mathrm{MgCl} 2,200 \diamond \mathrm{MdNTP}, 25$ pmol primer with cycling conditions, 1 cycle, $95^{\circ} \mathrm{C}, 3 \mathrm{~min} ; 25$ cycles, $95^{\circ} \mathrm{C}, 1 \mathrm{~min}, 52^{\circ} \mathrm{C}$, $1 \mathrm{~min}, 72^{\circ} \mathrm{C}, 2.5 \mathrm{~min}$ and $1 \mathrm{cycle}, 72^{\circ} \mathrm{C}, 5 \mathrm{~min}$. The PCR product was run on a $1 \%$ agarose gel to estimate size and amount of product obtained. The PCR product was then purified using a Qiagen column and sequenced completely by cycle sequencing and the aid of an $\mathrm{ABI}$ automated sequencer. A variety of primers, generating overlapping PCR products, were designed to complete the sequence of the EST by PCR and sequencing (not shown).

Analyses of the 24B sequences were performed in various ways. The non-redundant nucleotide sequence database maintained by the National Center for Bioinformatics (NCBI) and the Apicomplexa nucleotide sequence database at the Parasite Genome Blast Server (PGBS; http://www.ebi.ac.uk/parasite/parasite_blast server.html) were searched with the sequences obtained using the programs BlastN and TBlastX in order to detect homologies with nucleotide sequences currently in the nucleotide sequence databases. Further searches were also made of specific parasite databases of ESTs and genomic sequences (e.g. ToxoDB; http://www.toxodb.org/toxo/home.jsp). ESTs of N. caninum, homologous to 24B, were identified by BLAST searching of an EST database (http://compbio.dfci.harvard.edu/tgi/protist.html).

\subsubsection{Cloning of 24B into pET25b}

PCR was carried out with primers pET25-24BORF2F $\left(5^{\mathrm{t}}\right.$ ACGCATGAATTCTATGGATCCTAAAGTGGAGAGT - $3^{\mathrm{t}}$ ) and pET2524BORF2R2 $\left(5^{\mathrm{t}}-\right.$ CATGACCTCGAGGACGCGCGGAACACCGTA $\left.-3^{\mathrm{t}}\right)$ using PCR cycling conditions as follows $94^{\circ} \mathrm{C} \times 2 \mathrm{~min} 1$ cycle; $94^{\circ} \mathrm{C} \times 45 \mathrm{~s}, \quad 50^{\circ} \mathrm{C} \times 45 \mathrm{~s}, 72^{\circ} \mathrm{C} \times 1.5 \min 28$ cycles $72^{\circ} \mathrm{C} \times 5 \mathrm{~min} 1$ cycle. The PCR product was purified using a Qiagen PCR purification kit and then digested at $37^{\circ} \mathrm{C}$ for $3 \mathrm{~h}$ with EcoRI and XhoI. The restriction digest was then purified with a Qiagen kit before ligation. Ligation was performed overnight at $4 \mathrm{C}$ with EcoRI/XhoI cut $\mathrm{pET} 25 \mathrm{~b}$ vector. The ligation was transformed into Top 10 competent cells and recombinants selected on agar plates containing ampicillin. Recombinant colonies were screened using vector based primers (T7 promoter $5^{\mathrm{t}}$ TTAATACGACTCACTATAGGG ${ }^{\mathrm{t}}$ and $\mathrm{T} 7$ terminator $5^{t}$ GCTAGTTATTGCTCAGCG $^{t}$ ) to assess the size of the insert. A selection of colonies that appeared to have the correct insert size was then sequenced to check the integrity of the construct.

\subsubsection{Purification of His-tagged 24B from E. coli}

Escherichia coli (containing recombinant pET25b) from $50 \mathrm{ml}$ L-broth cultures were pelleted and resuspended in $4 \mathrm{ml}$ of lysis buffer (50 mM NaH $\mathrm{PO}_{4}, \mathrm{pH} 8.0,300 \mathrm{~mm} \mathrm{NaCl}, 10 \mathrm{~mm}$ imidazole) containing lysozyme. After lysis by sonication the cell debris was removed by centrifugation and recombinant protein was bound to a Ni-NTA resin by mixing for $1 \mathrm{~h}$ at $4{ }^{\circ} \mathrm{C}$ after which the slurry was transferred to a $5 \mathrm{ml}$ disposable column (Qiagen). Contaminating proteins were removed by washing the column with $8 \times 5 \mathrm{ml}$ washes with $50 \mathrm{mM} \mathrm{NaH} \mathrm{PO}_{4}, \mathrm{pH} 8.0,300 \mathrm{~mm} \mathrm{NaCl}, 20 \mathrm{mM}$

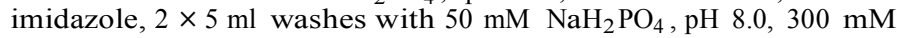
$\mathrm{NaCl}, 50 \mathrm{mM}$ imidazole and $2 \times 2.5 \mathrm{ml}$ washes of $50 \mathrm{mM} \mathrm{NaH} \mathrm{PO}_{4}$, $\mathrm{pH} 8.0,300 \mathrm{mM} \mathrm{NaCl}, 70 \mathrm{mM}$ imidazole. Protein was eluted off in $2 \times 2.5 \mathrm{ml}$ elutions of $50 \mathrm{mM} \mathrm{NaH} \mathrm{PO}_{4}, \mathrm{pH} 8.0,300 \mathrm{~mm} \mathrm{NaCl}$, $100 \mathrm{mM}$ imidazole and $1 \times 2.5 \mathrm{ml}$ elutions of $50 \mathrm{mM} \mathrm{NaH}{ }_{2} \mathrm{PO}_{4}, \mathrm{pH}$ $8.0,300 \mathrm{mM} \mathrm{NaCl}, 250 \mathrm{mM}$ imidazole. Elutions were checked for the presence of protein by SDS-PAGE and then dialysed against $0.9 \%$ saline. The amount and purity of protein recovered was estimated by assaying with Bradford reagent (Biorad) and SDS-PAGE respectively and then the protein was lyophilised and stored at $-20^{\circ} \mathrm{C}$. A sample of the protein was analysed by Western blotting using an antibody raised against the His-tag (Qiagen) to verify the presence of the fusion protein. 
Table 1

Assessment of vaccine potential-Experiment 1

\begin{tabular}{|c|c|c|c|c|c|}
\hline \multirow[t]{2}{*}{ Group } & \multirow[t]{2}{*}{ Treatment } & \multirow{2}{*}{$\begin{array}{l}\text { Total number of dams/average } \\
\text { litter size }( \pm \text { S.E. })\end{array}$} & \multirow{2}{*}{$\begin{array}{l}\text { Number of live/dead } \\
\text { pups/total }\end{array}$} & \multirow{2}{*}{\multicolumn{2}{|c|}{$\begin{array}{l}\text { Number of pups/number } \\
\text { positive for } \mathrm{N} \text {. caninum }\end{array}$}} \\
\hline & & & & & \\
\hline 1 & Challenge only & $8 / 13.9 \pm 1.4$ & $104 / 7 / 111$ & $100 / 76$ & $76^{\mathrm{b}}$ \\
\hline 2 & VSA- 3 control & $8 / 14.5 \pm 2.2$ & $112 / 4 / 116$ & $104 / 77$ & $74^{b}$ \\
\hline 3 & NC-Nowra infection & $10 / 14.1 \pm 1.7$ & $127 / 14 / 141$ & $123 / 10$ & $8^{\mathrm{a}, \mathrm{b}}$ \\
\hline 4 & NC-Nowra lysate & $9 / 13 \pm 2.1$ & $113 / 4 / 117$ & $104 / 65$ & $63^{\mathrm{a}, \mathrm{b}}$ \\
\hline 5 & MIC10 & $6 / 14.5 \pm 1.9$ & $82 / 5 / 87$ & $79 / 52$ & 66 \\
\hline 6 & $\mathrm{p} 24 \mathrm{~B}$ & $9 / 16.1 \pm 1.6$ & $122 / 7 / 129$ & $105 / 74$ & 70 \\
\hline 7 & $\mathrm{MIC} 10+24 \mathrm{~B}$ & $6 / 16.3 \pm 0.8$ & $91 / 7 / 98$ & $69 / 35$ & $51^{\mathrm{a}}$ \\
\hline
\end{tabular}

a Significantly different to the control groups.

b From Miller et al. [14], Table 2, Experiment 3. These experiments were conducted at the same time as those shown in this table and so the data is directly comparable.

\subsection{Cloning and expression of GRA1, GRA2 and MIC10}

Similar procedures as described above were used for the expression and analysis of these molecules.

\subsubsection{Expression of NC-GRA1 in E. coli}

DNA from an EST previously identified bearing sequence homology to GRA1 was used as a template. PCR was performed with primers pTrcHisp24-F (5 ${ }^{\mathrm{t}}$ ACGGATGGATCCTATGCTAGGTGGCGGGCG3) and primer FpB to generate a PCR product from this EST that was digested to completion with BamH1 and Kpn1. The product was ligated into doubly digested (BamH1 and $\mathrm{Kpn} 1) \mathrm{p}$ TrcHis vector and transformed into E. coli strain TOP10 and recombinants identified by section on LB plates containing ampicillin (LBamp). Colonies were screened by PCR using primers pTrcHisp24-F and pTrcHisP24$\mathrm{R}\left(5^{\mathrm{t}}\right.$ TACCGAGAATTCCGCTAACCCATGCCGTCG $\left.3^{\mathrm{t}}\right)$ and sequencing to check for the presence of inserts that were correctly in frame.

For protein purification cultured bacteria were resuspended in $10 \mathrm{ml}$ of lysis buffer $(20 \mathrm{mM}$ sodium phosphate, $500 \mathrm{mM} \mathrm{NaCl} \mathrm{pH}$ 7.8) containing $0.1 \mathrm{ml}$ protease inhibitors (Sigma Cat. No. P-8849). Cells were lysed by freeze/thawing three times in liquid nitrogen $/ 37^{\circ} \mathrm{C}$ water bath and sonicated for $2 \times 30 \mathrm{~s}$ at $50 \mathrm{~W} / 20 \mathrm{kHz}$. Cell debris was removed by centrifugation at $10,000 \mathrm{~g}$ and the supernatant (corresponding to the soluble fraction) retained.

Recombinant protein was purified from the supernatant by $\mathrm{Ni}$ NTA agarose affinity chromatography. Contaminating proteins were eliminated by washing the resin with $20 \mathrm{mM}$ sodium phosphate, $500 \mathrm{mM} \mathrm{NaCl} \mathrm{pH} 6$ followed by washes with $20 \mathrm{mM}$ sodium phosphate, $500 \mathrm{mM} \mathrm{NaCl} \mathrm{pH} \mathrm{5.5.} \mathrm{Fusion} \mathrm{protein} \mathrm{was} \mathrm{then} \mathrm{eluted} \mathrm{from}$ the resin using $20 \mathrm{mM}$ sodium phosphate, $500 \mathrm{mM} \mathrm{NaCl} \mathrm{pH} 4$. Yield per $50 \mathrm{ml}$ aliquot from a large culture was estimated at $250 \mathrm{~g}$.

\subsubsection{Expression of NC-GRA2 in E. coli}

The cloning of the GRA2 ORF into the pTrcHis vector was previously described [12]. Large-scale growth and induction of expression was done as described above for GRA1. Small-scale expression experiments demonstrated that most of the GRA2 was primarily present in the insoluble subcellular fraction so it was purified under denaturing conditions as follows. Bacteria were resuspended in $4 \mathrm{ml}$ of lysis buffer $(6 \mathrm{M}$ Guanidiniun $\mathrm{HCl}, 0.1 \mathrm{M}$ $\mathrm{NaH}_{2} \mathrm{PO}_{4}, 0.01 \mathrm{M}$ Tris- $\mathrm{Cl}$, pH 8.0 or $8 \mathrm{M}$ urea, $0.1 \mathrm{M} \mathrm{NaH}_{2} \mathrm{PO}_{4}, 0.01 \mathrm{M}$ Tris- $\mathrm{Cl}, \mathrm{pH}$ 8.0) plus protease inhibitors and lysoszyme. They were incubated on ice for $30 \mathrm{~min}$ and then sonicated for $2 \times 10 \mathrm{~s}$ at $50 \mathrm{~W} / 40 \mathrm{kHz}$. Cell debris was removed by centrifugation at $10,000 \mathrm{~g}$. Recombinant protein was purified from the supernatant by Ni-NTA agarose affinity chromatography. Resin was washed with $8 \mathrm{M}$ urea, $0.1 \mathrm{M} \mathrm{NaH}_{2} \mathrm{PO}_{4}, 0.01 \mathrm{M}$ Tris- $\mathrm{Cl} \mathrm{pH} 6.3$ and protein was then eluted using four column volumes of $8 \mathrm{M}$ urea, $0.1 \mathrm{M} \mathrm{NaH}_{2} \mathrm{PO}_{4}, 0.01 \mathrm{M}$ Tris- $\mathrm{Cl}$ pH5.9 and four volumes of $8 \mathrm{M}$ urea, $0.1 \mathrm{M} \mathrm{NaH}_{2} \mathrm{PO}_{4}, 0.01 \mathrm{M}$ Tris-Cl pH 4.5 .

\subsubsection{Expression of NC-MIC10 in E. coli}

The cloning of MIC10 was previously described by us (previously known as P20) [16]. RACE Ready cDNA was used as a template for PCR using gene specific primers p30-ATG2F $\left(5^{\mathrm{t}}\right.$ ACGTATGGATCCGGCTTTGTCTACGATGAAC $\left.3^{\mathrm{t}}\right)$ and pET25-p20R4 $\left(5^{\mathrm{t}}\right.$ ACGTATAAGCTTTGCCTTCTTGCGGGCCGCGA $\left.3^{\mathrm{t}}\right)$. The PCR product was purified and doubly digested with the enzymes BamH1 and Hind111, after which the product was further purified and ligated into BamH1 and Hind111 digested pET25b vector. Recombinants were selected by transformation into E. coli as described for $24 \mathrm{~B}$ and clones for expression studies were screened by PCR and sequencing as described above.

\subsection{Assessment of Vaccine Potential}

Two independent experiments were conducted (Tables 1 and 2) using the immunization strategy and mouse model described in detail elsewhere $[14,17]$. Briefly female Qs mice at 4-5 weeks of age were divided into groups that were injected subcutaneously

Table 2

Assessment of vaccine potential-Experiment 2

\begin{tabular}{|c|c|c|c|c|c|}
\hline \multirow[t]{2}{*}{ Group } & \multirow[t]{2}{*}{ Treatment } & \multirow{2}{*}{$\begin{array}{l}\text { Total number of dams/average } \\
\text { litter size }( \pm \text { S.E. })^{\mathrm{a}}\end{array}$} & \multirow{2}{*}{$\begin{array}{l}\text { Number of live/dead } \\
\text { pups/total }\end{array}$} & Number of pups/number & $\%$ Positive pups \\
\hline & & & & \multicolumn{2}{|l|}{ positive for N. caninum } \\
\hline 1 & Uninfected mice & $11 / 12.1 \pm 2.2$ & $97 / 25 / 122$ & $95 / 0$ & $0^{\mathrm{b}}$ \\
\hline 2 & Challenge only & $13 / 13.1 \pm 2.7$ & $118 / 24 / 142$ & $93 / 62$ & $74^{\mathrm{b}}$ \\
\hline 3 & VSA-3 control & $14 / 12.8 \pm 1.9$ & $151 / 49 / 200$ & $124 / 79$ & $64^{\mathrm{b}}$ \\
\hline 4 & NC-Nowra lysate & $12 / 14.6 \pm 1.5$ & $131 / 1 / 132$ & $114 / 60$ & $53^{\mathrm{b}}$ \\
\hline 5 & GRA-1 & $12 / 15.0 \pm 1.2$ & $150 / 3 / 153$ & $141 / 87$ & 63 \\
\hline 6 & GRA-2 & $12 / 8.1 \pm 2.7$ & $65 / 46 / 111$ & $55 / 37$ & 70 \\
\hline 7 & MIC10 & $11 / 11.4 \pm 2.2$ & $80 / 36 / 116$ & $70 / 47$ & 64 \\
\hline 8 & p24B & $10 / 14.5 \pm 1.9$ & $87 / 0 / 87$ & $83 / 50$ & 60 \\
\hline 9 & All 4 antigens & $9 / 8.6 \pm 2.4$ & $43 / 4 / 47$ & $42 / 26$ & 60 \\
\hline 10 & $\mathrm{MIC} 10+\mathrm{p} 24 \mathrm{~B}$ & $12 / 15.0 \pm 2.5$ & $120 / 12 / 132$ & $95 / 72$ & 76 \\
\hline
\end{tabular}

a Average litter size includes the live pups only, dams with no live pups are included in the calculation as a 0 .

b From Miller et al. [14], Table 2, Experiment 2. These experiments were conducted at the same time as those shown in this table and so the data is directly comparable. 
(s.c.) as detailed in Tables 1 and 2. VSA-3 was used an adjuvant (comprising $1 / 3 \mathrm{v} / \mathrm{v}$ of the immunogen) and $10 \mathrm{~g}$ of each recombinant protein or lysate was injected per mouse. Four weeks later the same mice were given a booster s.c. injection of the same formulation received earlier. 8-11 days later ovulation of the female mice was synchronised using pregnant mare serum gonadotrophin and human chorionic gonadotrophin, after which the females were housed overnight with stud males. Females were inspected for the presence of vaginal plugs and only the plugged females were kept for inclusion in the experiment (becoming the treatment groups). Unplugged mice were kept until challenge of the treatment groups, at which time they were euthanized to provide blood for immunoassay.

On day 5 of gestation, pregnant mice in the treatment groups were injected s.c with $10^{6}$ tachyzoites of NC-Liverpool recovered from in vitro culture as described above. A control group (pregnant uninfected mice) were injected s.c. with $0.9 \%$ saline. On approx. day 14 of gestation pregnant dams were placed in individual boxes and allowed to carry their pregnancy to term. Mice were checked daily until all that were obviously pregnant had given birth and the date of birth and number of pups (live and dead) noted. Differences in average litter sizes and the number of live and dead pups per group were analysed by Chi-square using the Instat program. Seven days after giving birth dams and surviving pups were euthanased, pup brains were removed and snap-frozen in liquid nitrogen before being transferred to $-20{ }^{\circ} \mathrm{C}$ for short-term storage. Dams were euthanased and blood collected by cardiac puncture for analysis of antibody levels.

All animal experiments were conducted with the approval of the UTS Animal Care and Ethics Committee.

\subsubsection{Immunogenicity of the recombinant proteins in mice}

Blood was collected from unplugged female mice via cardiac puncture and the serum obtained used to demonstrate $\operatorname{IgG}$ in the mice (by ELISA) to the recombinant proteins. NC-Nowra (or NCLiverpool) tachyzoites were recovered from in vitro culture and reduced to protein extracts by re-suspension in PBS and disruption by sonication at $50 \mathrm{~W} / 20 \mathrm{KHz}$ for $10-20 \mathrm{~s}$. Protein concentration was determined using the Bradford dye-binding assay (Biorad). Costar 96 well plates were coated with antigen diluted to $1 \mathrm{~g} /$ well in carbonate buffer $\left(70 \mathrm{mM} \mathrm{NaHCO} 3,29 \mathrm{mM} \mathrm{Na}_{2} \mathrm{CO}_{3}, 3.1 \mathrm{mM} \mathrm{NaN}\right.$, $\mathrm{pH}$ 9.6) at $4{ }^{\circ} \mathrm{C}$ overnight. Extra plates were coated with $19 \mathrm{~g} /$ well of the recombinant protein applicable to the group of mice being assayed. Plates were washed three times with $\mathrm{PBS} / 0.03 \%$ Tween (PBST) and serum diluted 1:100 in blocking buffer $(0.3 \%$ Tween, $0.05 \%$ bovine haemoglobin) was added to each well. Each sample was done in duplicate. Plates were incubated for $90 \mathrm{~min}$ at $37^{\circ} \mathrm{C}$ and then washed three times with PBST. Anti-mouse IgG-alkaline phosphatase conjugate was diluted 1:6000 in blocking buffer and added to wells and plates were incubated at $37^{\circ} \mathrm{C}$ for $1 \mathrm{~h}$. Plates were washed with PBST and $1 \mathrm{mg} / \mathrm{ml}$ of p-nitrophenylphosphate in carbonate buffer was added. Plates were incubated at $25^{\circ} \mathrm{C}$ for $30 \mathrm{~min}$ and absorbance at $405 \mathrm{~nm}$ read in a Biorad ELISA plate reader. Statistical analysis was performed using ANOVA and a Tukey-Kramer Multiple Comparison test. A P $<0.05$ was considered significant.

The level of IgG1 and IgG2a antibodies specific to $\mathrm{N}$. caninum in the serum from mice was also measured by ELISA with the following modification. Instead of anti-mouse IgG-Alkaline Phosphatase, anti-mouse IgG1-Biotin and anti-mouse IgG2a-Biotin antibodies were diluted 1:6000 in blocking buffer, added to wells and plates were incubated overnight at $4{ }^{\circ} \mathrm{C}$. They were then washed three times with PBST, and Extravidin-Alkaline Phosphatase at a dilution of 1:5000 in blocking buffer was added to the wells. These plates were incubated at $37^{\circ} \mathrm{C}$ for $1 \mathrm{~h}$ after which they were washed three times with PBST. p-Nitrophenylphosphate at a concentration of $1 \mathrm{mg} / \mathrm{ml}$ in developing buffer $\left(58 \mathrm{mM} \mathrm{NaHCO}{ }_{3}, 42 \mathrm{mM} \mathrm{Na} \mathrm{CO}_{3}\right.$, $\left.2 \mathrm{mM} \mathrm{MgCl} 2.6 \mathrm{H}_{2} \mathrm{O}, \mathrm{pH} 9.8\right)$ was added to the wells. Plates were incubated at $37{ }^{\circ} \mathrm{C}$ for $15 \mathrm{~min}$ and read at an absorbance of $405 \mathrm{~nm}$.

\subsubsection{Detection of N. caninum by PCR}

Individual pup brains were homogenised in $4 \mathrm{ml}$ of DNAzol [14]. Proteinase $\mathrm{K}$ was added to a final concentration of $400 \mathrm{~g} / \mathrm{ml}$ and tubes were left at room temperature overnight or until lysis was complete (i.e. no undigested tissue visible). $2 \mathrm{ml}$ of $100 \%$ ethanol was added and the tube inverted until DNA precipitation was complete. The DNA precipitate was transferred to a sterile tube and washed twice with 70\% DNAzol, 30\% ethanol and then once with $75 \%$ ethanol. All liquid was removed and the DNA pellet was resuspended in 750 sterile water. 2.5 of this DNA was used in each PCR reaction. PCR was carried out using primers (targeting the ribosomal DNA of N. caninum) CR3 (5 $5^{\mathrm{t}}$-ATATACTACTCCCTGTGAGTT$\left.3^{\mathrm{t}}\right)$ and CR4 (5 $5^{\mathrm{t}}$-GTAATCTGAAAGCGAATAGAG) or primers Tim3 $\left(5^{\mathrm{t}}\right.$-CCGCTGCAGAGGTGAACCTGCGGAAGGATC- $\left.{ }^{\mathrm{t}}\right)$ and Tim $11\left(5^{\mathrm{t}}-\right.$ CACTGAAACAGACGTACC- $3^{\mathrm{t}}$ ). Each PCR reaction consisted of $6.7 \mathrm{mM}$ Tris- $\mathrm{HCl}, 1.66 \mathrm{mM}\left(\mathrm{NH}_{4}\right)_{2} \mathrm{SO}_{4}, 0.45 \%$ Triton $\mathrm{X}-100,2 \mathrm{mg} / \mathrm{ml}$ gelatin, $2.5 \mathrm{mM} \mathrm{MgCl}_{2}, 0.2 \mathrm{mM} \mathrm{dNTPs}, 0.25 \mathrm{M}$ of each primer, and $1.1 \mathrm{U}$ of Taq polymerase (Biotech). Amplifications were performed on an MJ Research PTC-100. Thermocycling conditions consisted of 1 cycle of $95{ }^{\circ} \mathrm{C}$ for 2 min followed by 35 cycles of $95{ }^{\circ} \mathrm{C}$ for $45 \mathrm{~s}, 50{ }^{\circ} \mathrm{C}$ for $45 \mathrm{~s}$, $72{ }^{\circ} \mathrm{C}$ for $1 \mathrm{~min} 30 \mathrm{~s}$. Final cycle was $72^{\circ} \mathrm{C}$ for $5 \mathrm{~min}$. After amplification, $4 \uparrow 1$ from each reaction was loaded onto a $1 \%$ agarose gel and electrophoresed. Gels were stained with ethidium bromide and viewed on a transilluminator and photographed. The presence of N. caninum DNA was determined by the presence of a band of appropriate size in the PCR reaction. The numbers of positive and negative pups were tallied for each litter and each group and a percentage of transmission calculated. Percent transmission in groups was compared using a Chi-square test. A P $<0.05$ was considered significant.

\section{Results}

\subsection{Characterisation and expression of $24 \mathrm{~B}$}

The sequence compiled for the 24B cDNA was $1744 \mathrm{bp}$ long (56\% GC; with a poly A tail of 47 residues) and it contained a number of potential open reading frames (ORFs). A BlastN search of the NR Nucleic Acid database with the $5^{\mathrm{t}}$ untranslated region from the $24 \mathrm{~B}$ cDNA sequence revealed sequence similarities (67\% over 50 bases) to those found in the $3^{\mathrm{t}}$ untranslated regions of cytokine-like genes of mammals such as MIP-1 (HSMIP1A [18]) and LD78 (HSLD78A [19]).

Sequence homologies detected to T. gondii and Eimeria tenella sequences by database searching of parasite sequence databases pointed to the ORF being located between positions 628 and 1420 . This ORF was 729 bp long encoding a $27 \mathrm{kDa}$ polypeptide containing 243 amino acids. The first ATG codon in the $24 \mathrm{~B}$ gene is located at $628 \mathrm{bp}$ and is believed to be the start codon of this gene, as it is in a favourable context for initiating translation and there are no other ATG codons upstream [20].

A BlastN search of the TIGR N. caninum database (http://compbio.dfci.harvard.edu/tgi/cgi-bin/tgi/Blast/index.cgi) with the genomic sequence of $24 \mathrm{~B}$ revealed matches to a cluster of 22 ESTs comprising contig TC3100. All the ESTs were derived from tachyzoite cDNAs confirming the gene is expressed in the tachyzoite stage. PCR with 24B-specific primers demonstratrated the sequence was derived from the $\mathrm{N}$. caninum genome and not Vero, thereby confirming the parasite origin of the sequence. 
Initial attempts to express $24 \mathrm{~B}$ in the plasmid vector $\mathrm{pTrcHisB}$ gave a poor yield of protein from standard broth cultures. In addition, the protein failed to bind very tightly to the Ni-NTA resin and much was lost from the resin during the washing stages. Consequently cloning of the sequence into pET25b was performed. This resulted in much higher levels of $\mathrm{p} 24 \mathrm{~B}$ protein expression, which could be purified by Ni-NTA chromatography. The yield of recombinant $\mathrm{p} 24 \mathrm{~B}$ per $50 \mathrm{ml}$ culture was estimated at $80 \mathrm{~g}$.

\subsection{Immunogenicity of recombinant proteins}

ELISA was used to confirm the presence of antibodies to N. caninum proteins in sera collected from mice injected with the various formulations described in Tables 1 and 2. Examples of the results are shown in Fig. 1, which are derived from Experiment 1. All mice injected with lysate or tachyzoites produced high levels of IgG antibody that were detectable by ELISA using a lysate of NC-Nowra as the target antigen (Fig. 1, panels A and B). Mice injected with MIC10 and/or p24B produced responses that were barely detectable in this ELISA. However when recombinant protein was used as the target antigen in ELISA, antibody to them was detected.

For example, a significant amount of antibody $(\mathrm{P}<0.05)$ is detectable in Groups 4 (Nowra lysate), 5 (GRA-1), 6 (GRA-2) and 9 (GRA-1/GRA-2/p20/p24B) of Fig. 1 compared with Group 1 (control mice) showing an antibody response to the injections of lysate or recombinant antigen in these groups. No significant difference is seen between Group 1 and Groups 7 (MIC10), 8 (p24B) or 10 $(\mathrm{MIC} 10+\mathrm{p} 24 \mathrm{~B})$. However, when ELISAs were performed using the recombinant antigen injected as target antigen, significantly higher absorbances $(\mathrm{P}<0.05)$ were seen in all the treatment groups compared with sera from the control mice (Fig. 1; Panel C).

IgG1 and IgG2a ELISA's were also performed to determine the isotype of $\mathrm{N}$. caninum specific $\mathrm{IgG}$ that was produced in mice as a result of injection of the formulations (Fig. 1B). Both the groups injected with NC-Nowra lysate and live NC-Nowra had significant IgG1 and IgG2a antibody responses $(\mathrm{P}<0.05)$. The dominant antibody isotype produced in mice injected with $\mathrm{NC}$-Nowra lysate was IgG1, compared with a dominant IgG2a antibody response in mice vaccinated with live NC-Nowra parasites.

These results therefore confirmed that at the time of challenge, the injected mice had seroconverted to the antigen injected, thereby confirming that all 4 proteins are immunogens in mice.

\subsection{Assessment of vaccine potential}

\subsubsection{Experiment 1}

The results are summarized in Table 1 and transmission of the challenge strain was assessed by PCR of DNA extracted from the brains of 684 pups. Some of the data in Table 1 is from Miller et al. [14] and is reproduced here in order to allow complete representation of these studies. Average litter sizes ranged from $13 \pm 2.1$ in the NC-Nowralysate group to $16.3 \pm 0.8$ in the MIC10 + p24B group. There was no significant difference in the average litter size between any of the groups.

The rate of transmission in mice that received only the challenge infection (the positive control) was $76 \%$. Significant reductions in parasite transmission were observed in some treatment groups. Those injected with NC-Nowra lysate showed transmission to $63 \%$ of the pups, a reduction compared to the controls of $17.8 \%$ $(\mathrm{P}=0.0485)$. Those injected with live NC-Nowra only transmitted the infection to $8 \%$ of pups; a reduction in transmission rate of $90 \%(\mathrm{P}<0.0001)$. Both groups individually injected with recombinant antigens transmitted the challenge to $66 \%$ (MIC10) and $70 \%$ (p24B) of offspring, a reduction of 13.2 and $7.8 \%$ respectively. However, in the combined recombinant group $(\mathrm{MIC} 10+24 \mathrm{~B})$ only
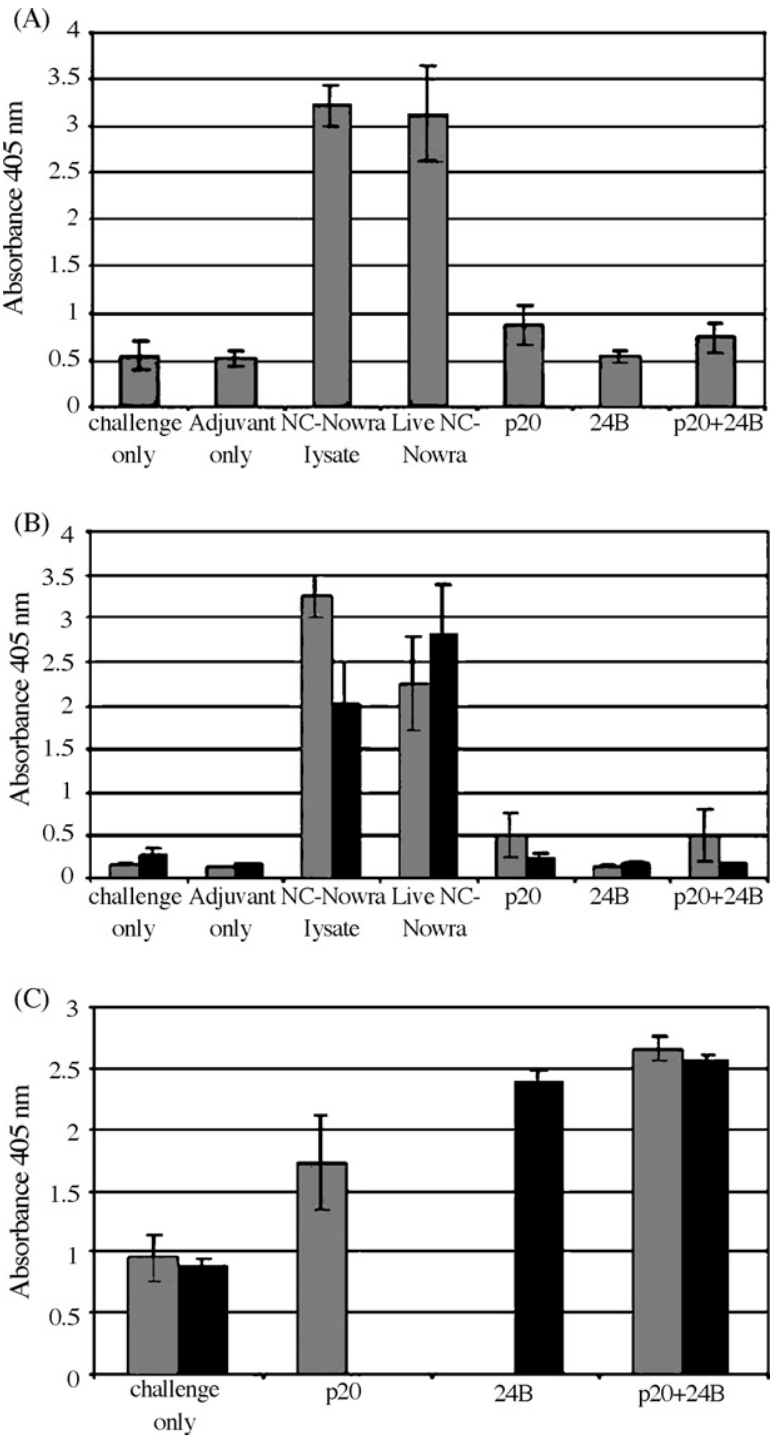

Fig. 1. ELISA results for $\mathrm{N}$. caninum specific $\operatorname{IgG}$ antibodies using serum from blood taken prior to challenge by NC-Liverpool. Blood was collected from unplugged mice on the day plugged mice received a challenge dose of $10^{6}$ NC-Liverpool. Columns represent the mean absorbance for each group and error bars are S.E. P20 is MIC10. (Panel A) The target antigen is lysate from NC-Nowra. Significant antibody responses were observed in mice injected with NC-Nowra lysate and live NC-Nowra parasites, compared to mice injected with saline $(\mathrm{P}<0.05)$. Assay is for IgG. (Panel B) The target antigen is lysate from NC-Nowra. ELISA profiles shown are for IgG1 and $\mathrm{IgG} 2 \mathrm{a}-$. Significant IgG1 antibody responses were observed in mice injected with NC-Nowra lysate and live NC-Nowra tachzyoites, compared with mice injected with saline $(\mathrm{P}<0.05)$. Significant IgG2a antibody responses were also observed in these mice, compared with mice given saline $(\mathrm{P}<0.05)$. The dominant antibody isotype produced in mice injected with NC-Nowra lysate was $\mathrm{IgG} 1$, in contrast mice injected with live NC-Nowra tachzyoites produced IgG2a as the dominant antibody isotype. (Panel C) The target antigen is either recombinant MIC10 or p24B protein - Mice injected with $\mathrm{MIC} 10+\mathrm{p} 24 \mathrm{~B}$ had a significantly greater MIC10 specific antibody response than mice vaccinated with $\mathrm{MIC10}$ alone or saline $(\mathrm{P}<0.05)$. Both mice injected with p24B alone and MIC10 + p24B had a significant p24B specific antibody response, compared with mice given saline $(\mathrm{P}<0.05)$.

$51 \%$ of offspring were positive, a reduction of transmission of $32.9 \%(\mathrm{P}=0.0009)$. The best performing "vaccine" was therefore live NC-Nowra. Within most groups once again, individual litter transmission rates were variable. For example in the NC-Nowra lysate group, rates varied from $13 \%$ to $100 \%$ transmission and in the $\mathrm{p} 24 \mathrm{~B}$ group rates varied from $0 \%$ to $100 \%$ transmission. 

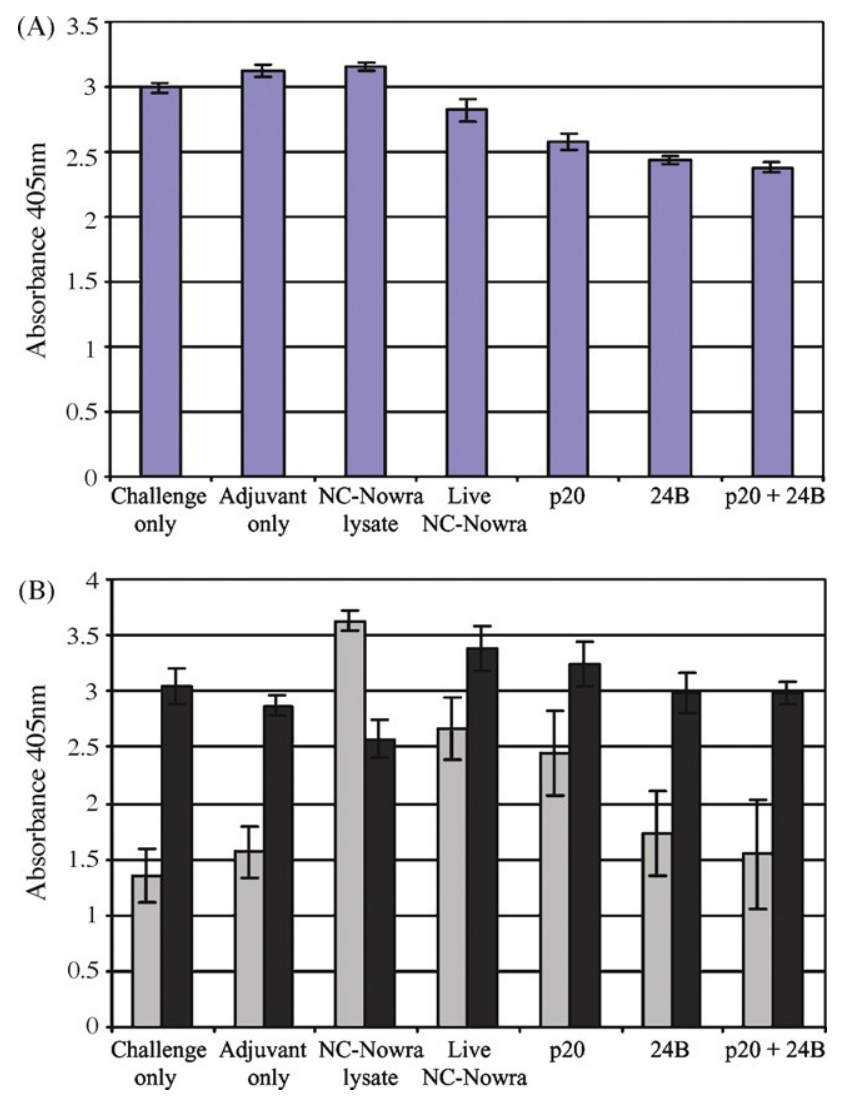

Fig. 2. Neospora caninum specific antibodies were detected by ELISA in serum from dams that had produced pups. (A) IgG and (B) IgG1 $\square$ and IgG2a - Columns represent the mean absorbance for each group and error bars are S.E. P20 is MIC10 All groups of mice had an IgG antibody response after challenge (A). All groups produced similar levels of $\mathrm{IgG} 2 \mathrm{a}$ antibodies and this was the dominant antibody isotype produced by all groups, except those mice that had previously been injected with NC-Nowra lysate. The level of IgG1 antibodies produced was variable among the mice groups, with the highest levels produced in the NC-Nowra lysate injected group (B)

All groups of mice after birth of their pups demonstrated an $\mathrm{N}$. caninum specific IgG antibody response (Fig. 2A) that was enhanced by the challenge given during pregnancy with $\mathrm{NC}$-Liverpool. The level of antibody produced in groups injected with recombinant proteins appeared lower than the level produced in the other four groups. IgG1 and IgG2a ELISA's were also performed on these serum samples, to see whether immunisation altered the type of IgG isotype produced after a parasite challenge. The dominant antibody isotype in all groups was IgG2a, except the group vaccinated with NC-Nowra lysate, where IgG1 remained the dominant antibody isotype (Fig. 2B).

\subsubsection{Experiment 2}

Table 2 shows the results of our second experiment to determine the ability of a range of formulations to prevent transplacental transmission of an N. caninum challenge during pregnancy. Some of this data is from Miller et al. [14] and is reproduced here in order to allow complete representation of these studies. The percentage of dams who did not give birth or who only had dead pups varied considerably, however, a Chi-square analysis showed no significant difference between the groups. There was also no significant difference in the average litter size for each group compared with the uninfected and the infected control. However, the numbers of live pups in the treatment groups do differ significantly $(\mathrm{P}<0.05)$ from each other. Group 9 (GRA-1/GRA-2/MIC10/p24B) has a signif- icantly lower number of live pups compared with Group 4 (Nowra lysate; $\mathrm{P}=0.019$ ) and Group 5 (GRA-1; $\mathrm{P}=0.08$ ). Group 6 (GRA-2) is also significantly lower than Group 5 (GRA-1; $\mathrm{P}=0.0266$ ) and Group 10 (MIC10 + p24B; $\mathrm{P}=0.038$ ). There was no significant difference in the number of stillborn pups per group seen in Groups $1,2,3$ or 9 , however, the number of stillbirths was significantly lower compared with the uninfected control in Groups 4 (Nowra lysate; $\mathrm{P}<0.001), 5$ (GRA-1; $\mathrm{P}<0.001), 8(\mathrm{p} 24 \mathrm{~B} ; \mathrm{P}<0.001)$ and 10 $(\mathrm{MIC} 10+\mathrm{p} 24 \mathrm{~B} ; \mathrm{P}=0.0124)$ and significantly higher $(\mathrm{P}=0.0006)$ in Group 6 (GRA-2). Groups $4(\mathrm{P}<0.001), 5(\mathrm{P}<0.001), 7(\mathrm{P}=0.0114)$ and $8(\mathrm{P}<0.001)$ had a significantly lower number of stillbirths and Group $6(\mathrm{P}<0.001)$ a significantly higher number of stillbirths than the infected control (Group 2).

DNA was extracted from 927 of the 931 pups collected. The DNA from 4 of the samples was lost during the extraction process. PCR was done at least once on all remaining samples. All samples which gave a faint positive result were repeated and around 100 samples were randomly repeated to verify the results. Any unclear results obtained in the PCR using the CR3/CR4 primers were repeated with the Tim3/Tim11 primers for verification. The results obtained are summarized in Table 2. An overall transmission of $74 \pm 6.6 \%$ was found in the challenge-only control group (Group 2) with transmission rates varying from $48 \%$ to $100 \%$ amongst the litters. No evidence of transmission was found in the saline control group (which was not infected).

None of the treatment groups had a significantly reduced rate of fetal infection compared with the positive control group (Group 2). Transmission rates of $\mathrm{N}$. caninum did vary however extensively among the various treatment groups. For example, transmission in the group injected with NC-Nowra lysate was $50.4 \pm 9.4 \%$ while in the group injected with the combination of MIC10 + p24B the level was $76.3 \pm 7.6 \%$.

The rates of vertical transmission within the litters in each group were also quite variable - rates in Group 3 range from $7 \%$ up to $93 \%$; in Group 4 they range from $0 \%$ to $81 \%$; in Group 5 they range from $13 \%$ to $87 \%$; in Group 6 they range from $21 \%$ to $100 \%$; in Group 7 they range from $33 \%$ to $88 \%$; in Group 8 they range from $38 \%$ to $80 \%$; in Group 9 they range from $27 \%$ to $100 \%$ and in Group 10 they range from $39 \%$ to $100 \%$.

\section{Discussion}

Infection with the parasite N. caninum is widespread within all cattle producing countries of the world and abortion losses due to neosporosis represent a major economic challenge [1]. As treatment options are largely impractical (due to the size of the animals involved and retention of residues) and as yet largely unexplored, the market for a possible vaccine is therefore globally significant and so the development of vaccines for neosporosis represents a significant commercial opportunity within the animal health industry. Clearly a vaccine that prevents infection by N. caninum in cattle may differ significantly in its form from a vaccine that prevents abortion. Prior knowledge on the development of vaccines against other parasites (such as the one developed against a closely related parasite, $\mathrm{T}$. gondii) suggests the latter is more likely to be developed and to be efficacious.

Although vaccines for parasites, based on recombinant proteins, have been promised for a long time, few have actually been achieved. Recombinant vaccines should be able to be more easily and more cost-effectively produced. A subunit vaccine for poultry coccidiosis is available [21], however because the vaccine is based on native proteins, it is difficult to manufacture. Nevertheless the vaccine has now been used in millions of chickens around the world, thereby confirming the need for a commercial vaccine. The greatest 
success stories thus far, are the development of highly efficacious recombinant vaccines for Taenia ovis in sheep, Taenia saginata in cattle, Taenia solium in pigs and Echinococcus granulosus in livestock [22]. In the absence of commercial markets for these products in the developed world however, these vaccines have failed to prosper.

The aim of this study was to evaluate four recombinant proteins derived from N. caninum as the basis of a potential vaccine. Two of the proteins are well known (GRA1, GRA2) since they were first described in detail from $\mathrm{T}$. gondii. The fourth protein $\mathrm{p} 24 \mathrm{~B}$ is novel and not previously described before, despite the fact that a homologue of this gene was detected by database searches in T. gondii and E. tenella. A cDNA coding for this protein was initially identified as an EST possessing sequence similarity to a gene encoding a mammalian immunoregulatory molecule. Database searches with the 24B cDNA sequence identified a region within the $5^{\mathrm{t}}$ untranslated region that possessed sequence similarity with the $3^{t}$ untranslated region of the MIP1a cDNA. Blum et al. (1990) argued the $3^{t}$ untranslated region of this mRNA possessed important regulatory motifs such as the NFxB -binding site. However, none of these motifs appear to be in the region found in the 24B cDNA. The significance of the sequence similarity of the $\mathrm{N}$. caninum sequence to the data from MIP1a remains unknown, as does the function of this molecule in the tachyzoite. To date, we have been unable to determine the intracellular location of the native 24B polypeptide by fluorescent or IEM methods.

As an initial approach to the development of a vaccine against abortion in cattle we assessed the ability of various recombinant protein formulations to prevent transplacental transmission of a challenge infection in a pregnant mouse model. The model we used was described by us previously and is of the immunization/challenge type, in that mice are injected with potential vaccine formulations and then challenged during pregnancy by a virulent strain of N. caninum that we previously demonstrated is passed in utero to fetal mice $[14,17]$. Infection can then be monitored by PCR of DNA extracted from the brains of pups that are subsequently born. The model is complex and labour intensive, taking several months to complete. In addition the PCR of pup brains is also open to issues of contamination and assay sensitivity that may confound estimates of transmission. Despite these issues, the use of a mouse model remains a much more rapid and cost-effective approach for the preliminary assessment of vaccines than the use of a cattle model.

Our previous studies using this pregnant mouse model showed that a live infection with NC-Nowra tachyzoites given before pregnancy provided high levels of protection against fetal infection resulting from a challenge infection given during pregnancy [14]. Extension of these studies to cattle showed that cattle immunized with live tachyzoites were protected against a foetopathic challenge, whereas cattle injected with lysate were not [15]. Consequently we have pioneered with our studies on transplacental transmission in mice, since our data and experience suggest that protection against fetal infection in mice appears to be a reasonable predictor for protection against fetal loss in cattle [14,15].

Our results from the use of this pregnant mouse model show that, in contrast to the high level of protection induced by a live infection by NC-Nowra in preventing fetal infection in utero, the levels of protection provided by any of the recombinant proteins were, at best, minimal. A combination of MIC10 and p24B in experiment 1 did reduce fetal infection by 33\% (in one experiment only), which remains the best protection we have achieved to date with a recombinant protein or lysate.

The significance of the protection seen in these studies, however, was difficult to determine because of the degree of variation detected within and between the treatment groups. Nevertheless, the presence of strong protective immunity, when induced by a live infection, was easily detectable and suggests the mouse model is appropriate for assessment of vaccine formulations. One important observation that continues to emanate from our studies is the correlation of the $\operatorname{IgG}$ isotype profile and prevention of fetal infection in utero. A live infection by NC-Nowra produces a strong IgG2a response whereas a lysate produces a stronger IgG1 [23]. Interestingly the data on the recombinant proteins suggests the formulations also induced an antibody response that was similar to that produced by the lysate (i.e. a stronger IgG1 response) before a challenge was given. After challenge, when all groups of mice had a strong $\mathrm{N}$. caninum antibody response, the NC-Nowra lysate group was the only one that still had a dominant $\mathrm{IgG} 1$ response. Those mice that were injected with either recombinant protein or a live infection showed a dominant IgG2a response. Previous studies with live infections have shown that an $\mathrm{IgG1}$ response in the mouse is not protective against N. caninum infection [24]. The importance of gamma interferon and a Th1 style immune response is well documented to be important in control of immunity to $\mathrm{N}$. caninum $[25,26]$.

These results suggest that more consideration should be given to the formulation of the immunogen, including trialing of other adjuvants that may induce an appropriate immune response, as monitored by the induction of IgG2a before challenge in this mouse model. VSA-3 was chosen for these studies as it is known to induce a strong Th1 response. The choice of antigens used in further vaccine trials will also be important.

Several studies have investigated the vaccine potential of proteins/antigens from N. caninum. One that is emerging as a strong vaccine candidate is SRS2 which is an antigen found on the surface of the tachyzoite. Ironically, in the mouse it induces a Th2 style immune response that prevents transplacental transmission in the mouse of a challenge infection [27]. Expression of SRS2 from live expression vectors based on vaccinia virus or Brucella abortus provided protection against fetal infection [28] or a lethal infection in mice [29]. Surprisingly SRS2 expressed in B. abortus did not provide protection against fetal infection in another study [30] and it is not clear why. In passing we note that a live B. abortus vector is unlikely to be acceptable in a commercial vaccine formulation, in particular in countries that have achieved freedom from brucellosis in their livestock.

GRA2 is another immunodominant antigen of N. caninum [12]. Within the field of toxoplasmosis, it has received a great deal of attention because of its important role as a dense granule protein that is involved in the biology of the parasitophorous vacuole [31]. In our studies we were unable to demonstrate any evidence that this antigen is a promising vaccine candidate, even though expression in B. abortus resulted in the induction of partial protection against fetal infection in a pregnant mouse model [30]. Clearly the method of delivery of an antigen can, like many other variables in vaccination, also influence the outcome of the vaccination process.

The present study shows that the recombinant antigens delivered in the present formulations provided only limited amounts of protective immunity in the mouse model. This may be related to the type of immune response that was induced, and future work with recombinant proteins might be directed at trying to drive the host's immune response towards an $\operatorname{IgG} 2$ (Th1) - type response. The pregnant mouse model may thus continue to be of on-going use in trialing vaccine candidates for the prevention of $\mathrm{N}$. caninum infections.

Attenuated live vaccines are attractive as the basis of a live "vaccination" approach to control bovine abortion due to neosporosis. A number of approaches for attenuation are possible and some have been described for N. caninum. Temperature sensitive mutants of $\mathrm{N}$. caninum were generated that did not persist or cause obvious pathology in the brain of infected mice [32]. Another approach 
involved irradiation of tachyzoites, a treatment that suppressed parasite multiplication leading to a parasite population that was attenuated in their ability to cause disease in the mouse [33]. Both of these approaches, however, lead to the generation of mutant populations of parasites, whose genotypes and phenotypes are not well defined. Vaccination with a naturally attenuated isolate of $\mathrm{N}$. caninum (NC-Nowra) provides a high level of protection against transplacental transmission of N. caninum in mice [14] and foetal loss in cattle [15]. The risks associated with using live parasite populations as live vaccines in cattle may be significant, and the potential for reversion to a disease causing phenotype is always a concern. It remains to be seen whether a live vaccine can become a commercial reality, however data on the prevalence of N. caninum in cattle suggests that a viable market exists for such a product $[1,34]$.

\section{Acknowledgements}

We thank P. Pratley for assistance with the DNA sequencing and J. Lopez for help in purifying proteins. This work was funded in part by Novartis Animal Vaccines (Braintree, U.K.). We also thank Sandy Trees and Diana Williams (Liverpool University) for their valuable discussion on this project.

\section{References}

[1] Reichel MP, Ellis JT. If control of Neospora caninum infection is technically feasible does it make economic sense? Vet Parasitol 2006;142(November $(1-2)): 23-34$.

[2] Reichel MP, Ellis JT. Controloptions for Neospora caninum in cattle. New Zealand Vet J 2002;50(1):86-92.

[3] Bigalke RD, Schoeman JH, McCully RM. Immunization against bovine besnoitiosis with a live vaccine prepared from a blue wildebeest strain of Besnoitia besnoiti grown in cell cultures 1 . Studies on rabbits. Onderstepoort J Vet Res 1974;41(1): $1-5$.

[4] Buxton D, Innes EA. A commercial vaccine for ovine toxoplasmosis. Parasitology 1995;110(Suppl.):S11-6.

[5] Shirley MW, Bedrnik P. Live attenuated vaccines against avian coccidiosis - success with precocious and egg-adapted lines of Eimeria Parasitol Today 1997;13(12):481-4.

[6] Barajas-Rojas J, Mapes G, Yanez I, Morales E, Lastra G. Field efficacy of a field vaccine against Neospora caninum in Mexico. In: Proceedings of XXIII World Buiartics Congress. 2004. p. 615. Abstract 403.

[7] Romero JJ, Perez E, Frankena K. Effect of a killed whole Neospora caninum tachyzoite vaccine on the crude abortion rate of Costa Rican dairy cows under field conditions. Vet Parasitol 2004;123(September (3-4)):149-59.

[8] Heuer C, Nicholson C, Russell D, Weston J. Field study in dairy cattle from New Zealand. In: Intervet Symposium: bovine neosporosis (Editor: T. Schetters). Vet Parasitol 2004; 125(October (1-2)):137-146.

[9] Muñoz Bielsa J, Romero JJ, Heuer C. Control of neosporosis in cattle with Bovilis Neoguard: the field experience. In: Intervet Symposium-World Buiatrics Conference. 2004.

[10] Hemphill A, Fuchs N, Sonda S, Hehl A. The antigenic composition of Neospora caninum. Inter J Parasitol 1999;29(8):1175-88.

[11] Hemphill A, Vonlaufen N, Naguleswaran A. Cellular and immunological basis of the host-parasite relationship during infection with Neospora caninum. Parasitology 2006;133(September (Pt 3)):261-78.

[12] Ellis JT, Ryce C, Atkinson R, Balu S, Jones P, Harper PA. Isolation, characterization and expression of a GRA2 homologue from Neospora caninum. Parasitology $2000 ; 120(4): 383-90$
[13] Li L, Brunk BP, Kissinger JC, Pape D, Tang K, Cole RH, et al. Gene discovery in the Apicomplex as revealed by EST sequencing and assembly of a comparative gene database. Genome Res 2003;13(3):443-54.

[14] Miller C, Quinn H, Ryce C, Reichel MP, Ellis JT. Reduction in transplacental transmission of Neospora caninum in outbred mice by vaccination. Inter J Parasitol 2005;35:821-8.

[15] Williams DJ, Guy CS, Smith RF, Ellis J, Bjorkman C, Reichel MP, et al. Immunization of cattle with live Tachyzoites of Neospora caninum confers protection against Fetal death. Infect Immun 2007;75(3):1343-8.

[16] Atkinson RA, Ryce C, Miller CM, Balu S, Harper PA, Ellis JT. Isolation of Neospora caninum genes detected during a chronic murine infection. Inter J Parasitology 2001;31(1):67-71.

[17] Quinn HE, Miller CM, Ryce C, Windsor PA, Ellis JT. Characterization of an outbred pregnant mouse model of Neospora caninum infection 2002:691-6.

[18] Blum S, Forsdyke RE, Forsdyke DR. Three human homologs of a murine gene encoding an inhibitor of stem cell proliferation. DNA Cell Biol 1990;9(October (8)):589-602.

[19] Nakao M, Nomiyama H, Shimada K. Structures of human genes coding for cytokine LD78 and their expression. Mol Cell Biol 1990;10(July (7)): 3646-58.

[20] Seeber F. Consensus sequence of translational initiation sites from Toxoplasma gondii genes. Parasitol Res 1997;83(3):309-11.

[21] Wallach M. The importance of transmission-blocking immunity in the control of infections by apicomplexan parasites. Inter J Parasitol 1997;27(10): $1159-67$

[22] Lightowlers MW. Cestode vaccines: origins, current status and future prospects. Parasitology 2006;133(Suppl.):S27-42.

[23] Quinn HE, Miller CM, Ellis JT. The cell-mediated immune response to Neospora caninum during pregnancy in the mouse is associated with a bias towards production of interleukin-4. 2004;34(6) 723-32.

[24] Baszler TV, McElwain TF, Mathison BA. Immunization of BALB/c mice with killed Neospora caninum tachyzoite antigen induces a type 2 immune response and exacerbates encephalitis and neurological disease. Clinical \& Diagnostic Laboratory Immunology 2000;7(6):893-8.

[25] Quinn HE, Ellis JT, Smith NC. Neospora caninum: a cause of immune-mediated failure of pregnancy? Trends Parasitol 2002;18(9):391-4.

[26] Williams DJ, Trees AJ. Protecting babies: vaccine strategies to prevent foetopathy in Neospora caninum-infected cattle. Parasite Immunol 2006;28(March (3)):61-7.

[27] Haldorson GJ, Mathison BA, Wenberg K, Conrad PA, Dubey JP, Trees AJ, et al. Immunization with native surface protein NcSRS2 induces a Th2 immune response and reduces congenital Neospora caninum transmission in mice. Int J Parasitol 2005;35(November (13)):1407-15.

[28] Nishikawa Y, Inoue N, Xuan X, Nagasawa H, Igarashi I, Fujisaki K, et al. Protective efficacy of vaccination by recombinant vaccinia virus against Neospora caninum infection. Vaccine $2001 ; 19(11-12): 1381-90$.

[29] Ramamoorthy S, Sanakkayala N, Vemulapalli R, Duncan RB, Lindsay DS, Schurig GS, et al. Prevention of lethal experimental infection of C57BL/6 mice by vaccination with Brucella abortus strain RB51 expressing Neospora caninum antigens. Int J Parasitol 2007;37(November (13)):1521-9.

[30] Ramamoorthy S, Sanakkayala N, Vemulapalli R, Jain N, Lindsay DS, Schurig GS, et al. Prevention of vertical transmission of Neospora caninum in C57BL/6 mice vaccinated with Brucella abortus strain RB51 expressing N. caninum protective antigens. Int J Parasitol 2007;37(November (13)):1531-8.

[31] Mercier C, Adjogble KD, Daubener W, Delauw MF. Dense granules: are they key organelles to help understand the parasitophorous vacuole of all apicomplexa parasites? Int J Parasitol 2005;35(July (8)):829-49.

[32] Dreier KJ, Stewarter LW, Kerlin RL, Ritter DM, Brake DA. Phenotypic characterisation of a Neospora caninum temperature-sensitive strain in normal and immunodeficient mice. Int J Parasitol 1999;29:1627-34.

[33] Ramamoorthy S, Lindsay DS, Schurig GG, Boyle SM, Duncan RB, Vemulapalli $\mathrm{R}$, et al. Vaccination with gamma-irradiated Neospora caninum tachyzoites protects mice against acute challenge with N. caninum. J Eukaryot Microbiol 2006;53(Mar-Apr (2)):151-6.

[34] Reichel MP, Ellis JT. Re-evaluating the economics of neosporosis control. Vet Parasitol 2008;156(3-4):361-2. 